\title{
A 15 year record of high-frequency, in situ measurements of hydrogen at Mace Head, Ireland
}

\author{
A. Grant ${ }^{1}$, C. S. Witham ${ }^{2}$, P. G. Simmonds ${ }^{1}$, A. J. Manning ${ }^{2}$, and S. O'Doherty ${ }^{1}$ \\ ${ }^{1}$ School of Chemistry, University of Bristol, UK \\ ${ }^{2}$ Met Office, FitzRoy Road, Exeter, Devon, UK \\ Received: 3 September 2009 - Published in Atmos. Chem. Phys. Discuss.: 25 September 2009 \\ Revised: 5 January 2010 - Accepted: 5 January 2010 - Published: 3 February 2010
}

\begin{abstract}
Continuous high-frequency measurements of atmospheric molecular hydrogen have been made at Mace Head atmospheric research station on the west coast of Ireland from March 1994 to December 2008. The presented data provides information on long term trends and seasonal cycles of hydrogen in background northern hemispheric air. Individual measurements have been sorted using a Lagrangian dispersion model to separate clean background air from regionally polluted European air masses and those transported from southerly latitudes. No significant trend was observed in background northern hemispheric air over the 15 year record, elevations in yearly means were accounted for from large scale biomass burning events. Seasonal cycles show the expected pattern with maxima in spring and minima in late autumn. The mean hydrogen mole fraction in baseline northern hemispheric air was found to be $500.1 \mathrm{ppb}$. Air transported from southerly latitudes showed an elevation from baseline mean of $11.0 \mathrm{ppb}$, reflecting both the latitudinal gradient of hydrogen, with higher concentrations in the Southern Hemisphere, and the photochemical source of hydrogen from low northern latitudes. European polluted air masses arriving at Mace Head showed mean elevation of $5.3 \mathrm{ppb}$ from baseline air masses, reflecting hydrogen's source from primary emissions like fossil fuel combustion. Forward modelling of transport of hydrogen to Mace Head suggests that the ratio of hydrogen to carbon monoxide in primary emissions is considerably less in non-traffic sources than traffic sources.
\end{abstract}

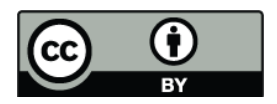

Correspondence to: A. Grant (aoife.grant@bristol.ac.uk)

\section{Introduction}

Hydrogen $\left(\mathrm{H}_{2}\right)$ is one of the most abundant trace gases in the atmosphere with a global average mole fraction of $530 \mathrm{ppb}$ (parts per $10^{9}$ molar) (Novelli et al., 1999) and a tropospheric lifetime of about 1.4 years. However, little attention had been paid to this influential trace gas until recently, due the possible introduction of $\mathrm{H}_{2}$ as a clean energy fuel alternative. $\mathrm{H}_{2}$ reacts with the hydroxyl radical $(\mathrm{OH})$ and thus acts as an indirect greenhouse gas, increasing the lifetime of methane $\left(\mathrm{CH}_{4}\right)$ and also affecting ozone $\left(\mathrm{O}_{3}\right)$ formation (Schultz et al., 2003; Warwick et al., 2004). $\mathrm{H}_{2}$ reacts with the $\mathrm{OH}$ to produce water vapour $\left(\mathrm{H}_{2} \mathrm{O}\right)$, which once transported to the stratosphere may have a cooling effect and decrease ozone layer recovery (Tromp et al., 2003). However the atmospheric effects of a $\mathrm{H}_{2}$ based fuel economy are still uncertain.

Sources and sinks of atmospheric $\mathrm{H}_{2}$ are well balanced, most recent estimates showing only small differences of $\sim 3 \mathrm{Tg} / \mathrm{yr}$ in some cases (Novelli et al., 1999; Ehhalt and Rohrer, 2009; Sanderson et al., 2003; Xiao et al., 2007). $\mathrm{H}_{2}$ sources can be separated into two major categories: surface sources, from direct emission, and photochemical sources, from oxidation of hydrocarbons. Small amounts of $\mathrm{H}_{2}$ are also emitted through biological activity of Rhizobium bacteria in the root nodules of plants and from oceanic bacteria (Seiler and Conrad, 1987; Novelli et al., 1999; Hauglustaine and Ehhalt, 2002; Sanderson et al., 2003; Rhee et al., 2006; Ehhalt and Rohrer, 2009). Surface sources include both direct emissions from fossil fuel combustion and emissions from biomass burning, both of which are closely related to carbon monoxide (CO) emissions. Thus, $\mathrm{H}_{2}$ budget estimates can be linked to the $\Delta \mathrm{H}_{2}: \Delta \mathrm{CO}$ ratio observed in urban locations or pollution plumes (Simmonds et al., 2000; Barnes et al., 2003; Steinbacher et al., 2007). These surface sources have been estimated to contribute equally to the $\mathrm{H}_{2}$ budget,

Published by Copernicus Publications on behalf of the European Geosciences Union. 
together accounting for $\sim 25 \mathrm{Tg} / \mathrm{yr} \mathrm{H}_{2}$. Photochemical production of $\mathrm{H}_{2}$ is solely through formaldehyde (HCHO) photolysis, thus production is highly dependent on actinic flux. This route accounts for approximately $40 \mathrm{Tg} / \mathrm{yr} \mathrm{H} \mathrm{H}_{2}$ (Ehhalt and Rohrer, 2009, and references therein). Methane almost quantitatively forms HCHO through removal by both oxidation and photolysis pathways, however $\mathrm{H}_{2}$ production from oxidation and photolysis of non-methane volatile organic compounds (NMVOCs) is much more complex and thus one of the most uncertain terms in the $\mathrm{H}_{2}$ global budget.

Sinks of $\mathrm{H}_{2}$ comprise the dominant biologically active soil sink and removal through oxidation by the hydroxyl radical. The $\mathrm{H}_{2}$ soil sink is the most difficult to estimate, contributing between $75-92 \%$ of its loss (Seiler and Conrad, 1987; Price et al., 2007; Xiao et al., 2007). Large variability in $\mathrm{H}_{2}$ deposition has been observed at the same sites, Yonemura et al. (2000) reported a range of $\mathrm{H}_{2}$ deposition velocities of $0-9 \times 10^{-2} \mathrm{~cm} \mathrm{~s}^{-1}$ from a year of chamber measurements taken in an arable field. The same soil types with differing vegetation also show large variation in deposition velocities, a recent study reported deposition velocities of 4.4 and $7.3 \times 10^{-2} \mathrm{~cm} \mathrm{~s}^{-1}$ over burned forest and mature forest sites (Rahn et al., 2002). The deposition velocity of $\mathrm{H}_{2}$ has been proven to vary with soil moisture, temperature, porosity, diffusivity and type (Conrad and Seiler, 1985; Yonemura et al., 1999; Yonemura et al., 2000; Rahn et al., 2002; Schmidt et al., 2008; Lallo et al., 2008), thus it is a complex process to model. An overall global $\mathrm{H}_{2}$ deposition velocity of $7 \times 10^{-2} \mathrm{~cm} / \mathrm{s}$ was first estimated by Seiler and Conrad (1985), however, more recent work by Sanderson et al. (2003) using a 3-D chemical transport model suggests a lower value of $5.3 \times 10^{-2} \mathrm{~cm} / \mathrm{s}$ is more representative globally, whilst other global models have found a deposition velocity of $3.9 \times 10^{-2} \mathrm{~cm} / \mathrm{s}$ produced the best agreement to surface measurements (Price et al., 2007). $\mathrm{H}_{2}$ has an unusual inter-hemispheric gradient since the Southern Hemisphere contains higher atmospheric mole fractions than the Northern Hemisphere, due to the larger land mass area in the Northern Hemisphere and thus greater removal through the soil sink. Inter-hemispheric gradients of 15-35 ppb have been reported in recent studies (Novelli et al., 1999; Simmonds et al., 2000; Xiao et al., 2007).

Surface observations of molecular $\mathrm{H}_{2}$ have been made since the 1950s (Glueckauf and Kitt, 1957) with measurements in polluted air masses following later (Schmidt, 1974). However, the first reported long-term studies of $\mathrm{H}_{2}$ were by Kahil and Rasmussen (1990) who reported a global average of $\sim 510 \mathrm{ppb}$ for 1988 from flask sampling between 1985 and 1989. These measurements showed an increasing trend in global $\mathrm{H}_{2}$ of $3.2 \pm 0.5 \mathrm{ppb} / \mathrm{yr}$. Novelli et al. (1999) taking weekly flask samples at 50 remote locations globally reported a global average of $531 \mathrm{ppb}$ from 1991-1996, with a downward trend of $-2.7 \pm 0.2 \mathrm{ppb} / \mathrm{yr}$ in the Northern Hemisphere. Simmonds et al. (2000) reported a mole fraction of $496.5 \mathrm{ppb}$ in northern hemispheric baseline air, with an upward trend of $1.2 \pm 0.8 \mathrm{ppb} / \mathrm{yr}$ from continuous, highfrequency measurements at Mace Head from 1994-1998. A slightly larger upward trend of $1.4 \pm 0.5 \mathrm{ppb} / \mathrm{yr}$ was more recently suggested from a global flask sampling campaign from 1992-1999 (Langenfelds et al., 2002).

Continuous high-frequency measurements of $\mathrm{H}_{2}$ have been performed at Mace Head since March 1994. This paper extends the observations of $\mathrm{H}_{2}$, recorded at this baseline site on the edge of the Eastern Atlantic from 1994 to 2008. This 15 year record is the longest known continuous record of $\mathrm{H}_{2}$ at a background northern hemispheric site to date. It provides essential information on long term trends of $\mathrm{H}_{2}$ in background northern hemispheric air alongside the effect of both European and Southerly transported air masses on background mole fractions. Forward modelling of $\mathrm{H}_{2}$ has been conducted to investigate the ratio of $\mathrm{H}_{2}$ to $\mathrm{CO}$ in primary emissions compared to those derived from the 15 year record at Mace Head. The results from this will help refine future modelling and lead to better assessments of the impacts of changing $\mathrm{H}_{2}$ emissions. Overall this 15 year dataset may provide essential information to improve assessments of the effect of a possible future $\mathrm{H}_{2}$ economy on atmospheric composition.

\section{Experimental}

\subsection{Sampling location}

Continuous measurements of $\mathrm{H}_{2}$ have been performed using an automated, high-frequency system at the Mace Head atmospheric research station since March 1994. The sampling site on the West coast of Ireland [53 $20^{\prime} \mathrm{N}, 9^{\circ} 54^{\prime} \mathrm{W}$ ] performs numerous other measurements as part of the Advanced Global Atmospheric Gases Experiment (AGAGE) (Cunnold et al., 1997; Prinn et al., 2000) and the Global Atmospheric Watch network (GAW). It is one of a few clean background Western European stations, thus providing essential baseline input for inter-comparisons with continental Europe, whilst also acting as a baseline site representative of northern hemispheric air. Polluted European air masses as well as tropical maritime air masses also cross the site periodically. Galway is the closest city, with a population of 72000 , sitting $50 \mathrm{~km}$ to the East whilst the area immediately surrounding Mace Head is very sparsely populated providing very low local anthropogenic emissions.

\subsection{Analytical Method and calibration}

A commercial gas chromatograph (Reduction Gas Analyser (RGA3), Trace Analytical, Inc., California, USA) was used to measure $\mathrm{H}_{2}$. This instrument is fitted with a mercuric oxide bed and, following its reduction, mercury vapour is measured by UV photometry. Injections made every $20 \mathrm{~min}$ alternated between analyses of air with a reference gas to determine and correct for instrumental drift, resulting in 36 fully 
calibrated air samples per day. Samples collected at an inlet $25 \mathrm{~m}$ above seas level were flowed through a temperature and pressure controlled environment before collection in a $1 \mathrm{ml}$ sample loop. Prior to separation samples were dried using a permeation Nafion drier (Permapure, USA). Working standards were prepared by compressing background ambient air at Trinidad Head, California into $35 \mathrm{~L}$ electropolished stainless steel canisters (Essex Cryogenics, Missouri, USA) using a modified oil-free compressor (SA-3, RIX California, USA). This means that $\mathrm{H}_{2}$ mole fractions in working standards are close in concentration to air sample values at Mace Head minimising non-linearities. $\mathrm{H}_{2}$ measurements, integrated by peak area, were referenced against a calibration scale developed at CSIRO (Commonwealth Scientific and Industrial Research Organisation) (Simmonds et al., 2000 and references therein). However inter-calibrations have been also carried out between the CSIRO scale and MPI2009 scale (A. Jordan, personal communication, 2009) with the RGA3 at Mace Head and show good agreement, with MPI2009 values approximately $16 \mathrm{ppb} \mathrm{H}_{2}$ higher than the CSIRO scale. Reported differences between CSIRO and MPI2009 scales are $16 \mathrm{ppb}$ at $460 \mathrm{ppb} \mathrm{H}_{2}$ rising to $17 \mathrm{ppb}$ at $570 \mathrm{ppb} \mathrm{H}_{2}$ (A. Jordan, personal communication, 2009).

Due to the non-linear response of the RGA3 detector, linearity testing was carried out during the reported measurement period. This was completed using a high concentration reference gas (BOC Speciality gases Ltd., Surrey, UK) which was dynamically diluted with zero air to the range of atmospheric concentrations by means of a custom made dynamic dilution unit. Results provided measurements for the non-linearity correction thus producing an equation to correct data for non-linearity. Precisions of better than $0.5 \%$ $(1 \sigma)$ for the 1995-2008 period were determined from recurrent working standard analyses for $\mathrm{H}_{2}$.

\section{Results and discussion}

The entire 15 year record of $\mathrm{H}_{2}$ observations every $40 \mathrm{~min}$ from March 1994 to December 2008 at the Mace Head atmospheric research station is shown in Fig. 1. Data coverage was $79 \%$ over this period with segments of missing data due to instrumental problems. $\mathrm{H}_{2}$ mole fractions ranged from a minimum of $420.9 \mathrm{ppb}$ to a maximum of $642.5 \mathrm{ppb}$ with a mean ( \pm standard deviation) of $503.2 \pm 17.6 \mathrm{ppb}$.

Data was sorted into air mass origins using the NAME Lagrangian atmospheric dispersion model (Jones et al., 2007) and the technique described in (Manning et al., 2003). This classified measurements into different sector types: baseline (Westerly or North Westerly airflow), European polluted, southerly transport, mixed (when air was from a variety of sectors), and local (times when there were low wind speeds and stable air so sources and sinks in the local region would significantly impact the observations). This air mass sorting method was demonstrated to be the most reliable by Sim-
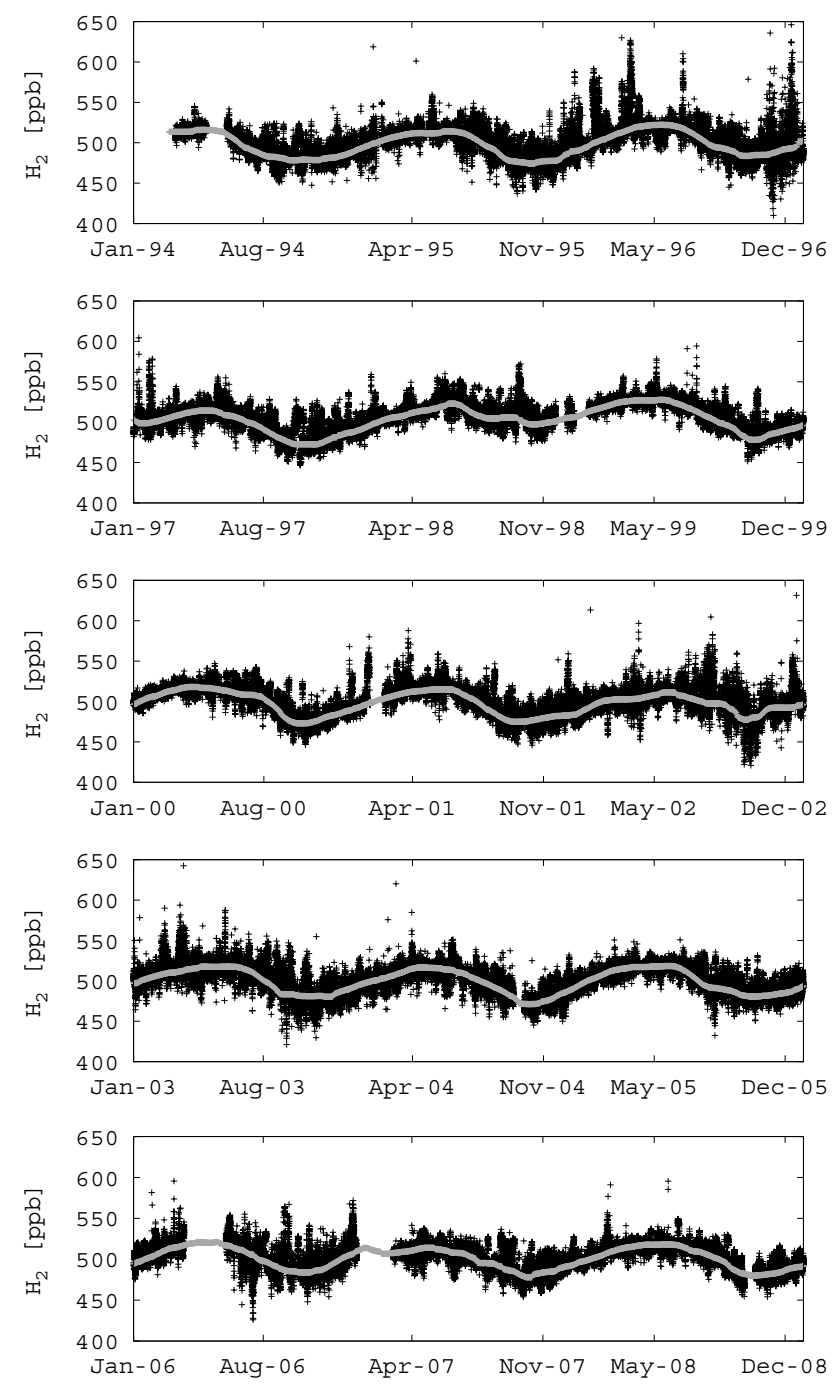

Fig. 1. Time series of 40-min $\mathrm{H}_{2}$ ambient air mole fractions at the Mace Head atmospheric research station during the period 19942008 with baseline values overlaid in grey.

monds et al. (2000) when compared to various other airattribution methods including $12 \mathrm{~h}$ isentropic back trajectories, daily wind direction sector allocation and halocarbon sorting.

\subsection{Baseline air masses}

Baseline air masses were defined as those which had negligible contributions from European or Southerly regions and were not unduly influenced by local factors. In 1994-2008, $37 \%$ of all of the $\mathrm{H}_{2}$ measurements were allocated as baseline air masses, with a mean $\mathrm{H}_{2}$ mole fraction of $500.1 \mathrm{ppb}$. In Fig. 2 we plot the monthly mean $\mathrm{H}_{2}$ in northern hemispheric baseline air, these data display both the seasonality and variability in mole fractions over the 15 year period. De-trended monthly mean values averaged over the 15 year dataset are 


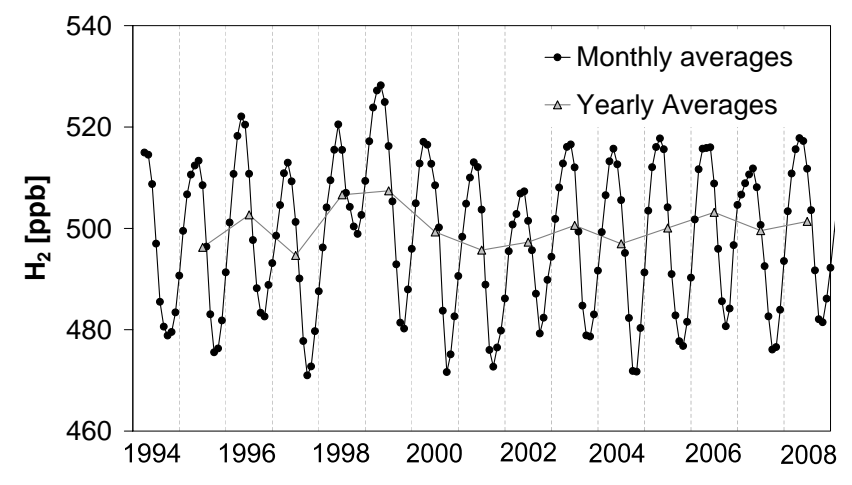

Fig. 2. Monthly and yearly mean $\mathrm{H}_{2}$ mole fractions in baseline air masses from March 1994 to December 2008.

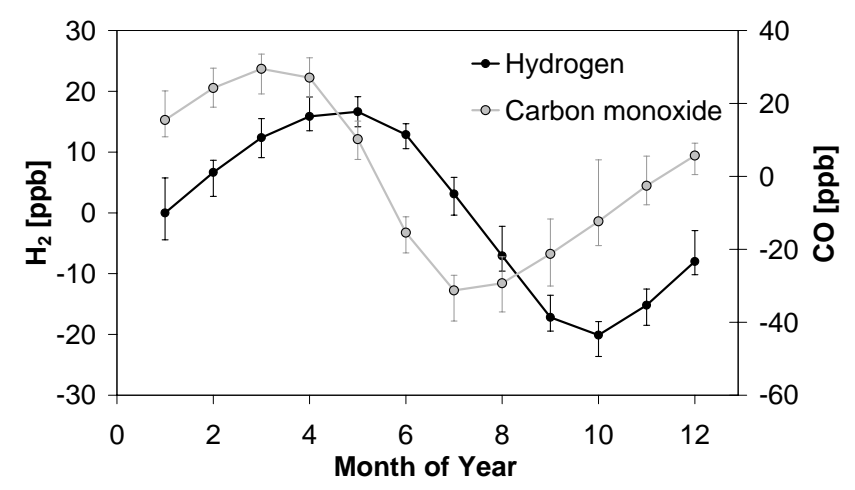

Fig. 3. De-trended average monthly means of $\mathrm{H}_{2}$ and $\mathrm{CO}$ mole fractions in baseline air masses from March 1994 until December 2008.

shown in Fig. 3. Data was de-trended to produce a monthly mean perturbation value $\left(S_{i}\right)$ for each month and year using Eq. (1):

$S_{i}=C_{i}-a_{i}$

Where $C_{i}$ is a monthly mean $\mathrm{H}_{2}$ concentration in baseline air and $a_{i}$ is the annual average baseline for month $i . a_{i}$ is calculated by fitting a quadratic function to five consecutive annual averages ( $a_{1}$ to $a_{5}$ ) centred on the current month of interest. $a_{i}$ is extracted from the quadratic fit and used to de-trend the data by subtraction from the monthly baseline concentration $\left(C_{i}\right)$. De-trended perturbation values $\left(S_{i}\right)$ are averaged for each month over the 15 year period studied to produce values in Fig. 3 where a distinct seasonal cycle with maxima from April to May and minima from September to October is observed in good agreement with previously reported studies at similar latitudes (Novelli et al., 1999; Barnes et al., 2003; Steinbacher et al., 2007). This study extends the four year dataset of Simmonds et al. (2000) at the same site, Simmonds et al. observed highest mole fractions in spring and lowest mole fractions in late autumn. Northern Hemisphere maxima and minima were observed by Novelli et al. (1999) in

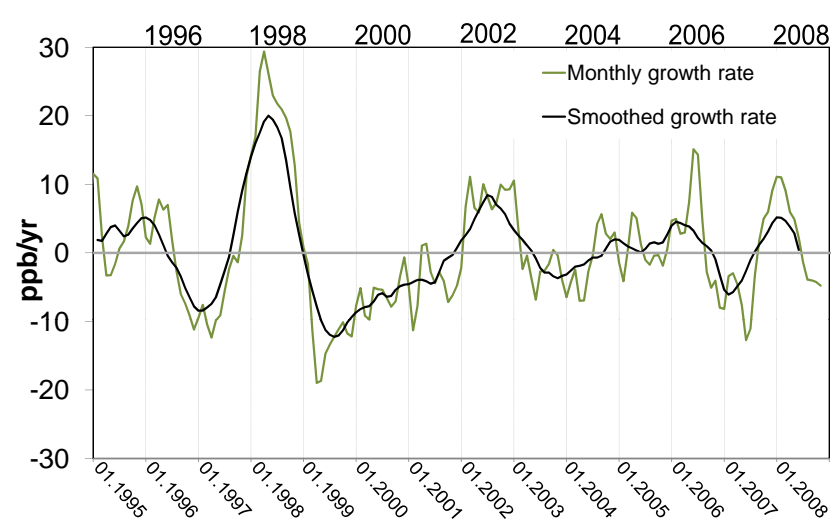

Fig. 4. Monthly and smoothed (through a 12-month running filter) growth rates of $\mathrm{H}_{2}$ mole fractions in baseline air masses.

late winter/early spring and autumn respectively. Steinbacher et al. (2007) also observed minima in autumn although sampling at a suburban site with considerable primary anthropogenic emissions. This highlights the importance of the dominant soil sink even in urban environments with limited soil surface areas. Barnes et al. (2003) sampled over a forest canopy and observed a broad maximum from early winter until early summer and short minima in late autumn. This observed seasonal cycle is a cumulative effect of maximum summertime loss rates by $\mathrm{OH}$ oxidation and strongest rates of soil uptake in late summer and early autumn when soils are driest (Conrad and Seiler, 1985; Yonemura et al., 2000; Schmitt et al., 2008). Mean seasonal background peak to trough amplitudes of $37 \pm 4 \mathrm{ppb}$ were observed at the Mace Head site, corresponding to a seasonal peak to trough cycle of $7 \%$ of the mean baseline $\mathrm{H}_{2}$ mole fraction. The $\mathrm{H}_{2}$ seasonal cycle follows the pattern of many other trace gases at the Mace Head site (Derwent et al., 1998), however $\mathrm{H}_{2}$ maxima are delayed by one to two months and $\mathrm{H}_{2}$ minima are delayed by two to three months, see Fig. 3 for comparison of the $\mathrm{H}_{2}$ and $\mathrm{CO}$ seasonal cycles. Both shifts are due to the dominant influence of the $\mathrm{H}_{2}$ soil sink, though as the soil sink is weaker in late winter the spring maximum is delayed by only one to two months, whilst the late summer minima is delayed by two to three months, since the soil sink has a much stronger influence at this time of year.

In contrast to previous literature no overall upward or downward trend in $\mathrm{H}_{2}$ mole fractions in baseline air masses was observed over the fifteen year period from visual inspection of both Figs. 2 and 4. These previous findings (see Sect. 1) are thought to be an artefact of the short time period over which these observations were made.

\subsubsection{Biomass burning}

Figure 4 shows a plot of monthly growth rates of $\mathrm{H}_{2}$ in baseline air masses from 1995-2009. Large elevations above the mean $\mathrm{H}_{2}$ mole fractions are observed in late 1998 and early 


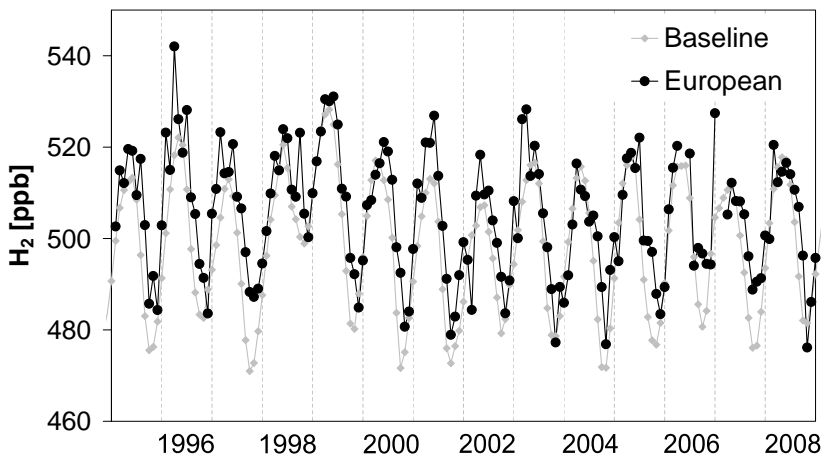

Fig. 5. Monthly mean $\mathrm{H}_{2}$ mole fractions from 1995 to 2008 in European and baseline air masses at Mace Head.

1999, whilst smaller elevations can be seen in late 1996, September 2002 and late 2006 (Figs. 2 and 4). These anomalous $\mathrm{H}_{2}$ events in 1998-1999 and 2002-2003 have been linked to concurrent perturbations in carbon dioxide $\left(\mathrm{CO}_{2}\right)$, $\mathrm{CO}, \mathrm{CH}_{4}, \mathrm{H}_{2}, \mathrm{O}_{3}$ and methyl chloride $\left(\mathrm{CH}_{3} \mathrm{Cl}\right)$; implying a relationship between large-scale biomass burning events and the inter-annual variability of these gases (Simmonds et al., 2005). Smoother correlative behaviour was observed in 1997-1998 between the gases, with concentrations of $\mathrm{CO}_{2}$, $\mathrm{CO}, \mathrm{CH}_{4}, \mathrm{H}_{2}, \mathrm{O}_{3}$ and $\mathrm{CH}_{3} \mathrm{Cl}$ rising and falling simultaneously, whilst during the 2002-2003 period a more complex pattern with slightly lower correlation between species was observed. This was attributed to the large contribution from tropical fires in 1998-1999: these fires burned for 2 years resulting in prolonged mixing into the background and longer transport times to the Mace Head site. In contrast, the fires in 2002-2003 burned predominantly in the Northern Hemisphere, resulting in a faster and more variable impact on the Mace Head baseline. An increase in $\mathrm{CO}$ was also observed in 2002-2003 from column measurements taken using an infrared spectrometer, this increase was linked to boreal forest fires in the high Northern Hemisphere with strong elevations seen in September 2002 and August 2003 (Yurganov et al., 2005). Long range transport of Siberian biomass burning emissions was also seen to impact measurements of ozone in North America in summer of 2003 (Jaffe et al., 2004). Both of these biomass burning events would have impacted the Mace $\mathrm{Head} \mathrm{H}_{2}$ baseline. Elevations in 1996 may be linked to long range transport from Siberian fires and biomass burning emissions in far east Russia (Duncan et al., 2003; Jaffe et al., 2004). Elevations of $\mathrm{H}_{2}$ in 2006 can be attributed to biomass burning in the Baltic countries, western Russia, Belarus and the Ukraine where biomass burning was reported in early summer, but may also have been prevalent in the following months affecting the Mace Head baseline (Stohl et al., 2007).

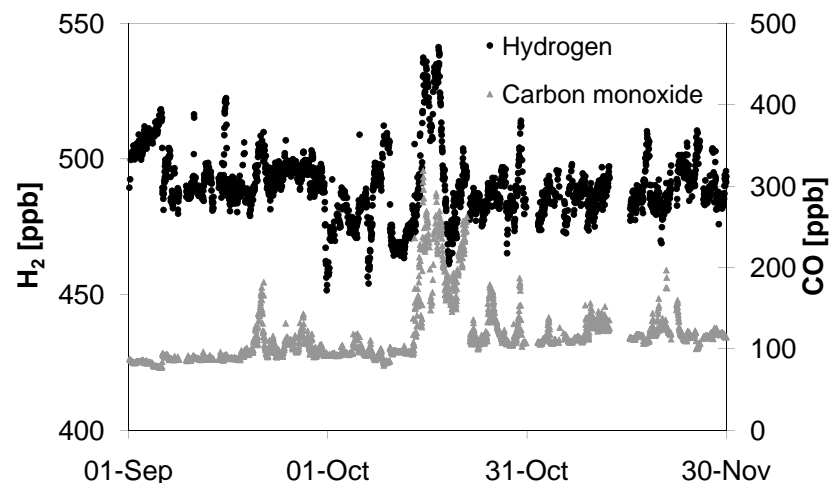

Fig. 6. Comparison of $\mathrm{H}_{2}$ and $\mathrm{CO}$ mole fractions from September to November, 1999.

\subsection{European pollution events}

In Fig. 1 periods of intensely elevated $\mathrm{H}_{2}$ above the baseline that last many days can be seen. These $\mathrm{H}_{2}$ peaks are due to the arrival of European polluted air masses at Mace Head during north-easterly through to south-easterly air flows, providing a mean polluted $\mathrm{H}_{2}$ mole fraction of $505.2 \mathrm{ppb}$ (see Fig. 5 for monthly averages). We estimate that European pollution events accounted for $23 \%$ of air masses arriving at Mace Head during the 15 year period studied. During these European "non-local" pollution events a strong correlation is observed between $\mathrm{H}_{2}$ and $\mathrm{CO}$, as seen for certain periods in Fig. 6 where most elevations in $\mathrm{H}_{2}$ correspond to enhanced $\mathrm{CO}$ mole fractions. This correlation between $\mathrm{H}_{2}$ and $\mathrm{CO}$ during European events indicates the anthropogenic origin of the peaks in $\mathrm{H}_{2}$ observed at these times since $\mathrm{CO}$ is emitted almost entirely from man-made sources, namely combustion sources and hydrocarbon oxidation (Khalil and Rasmussen, 1990). Figure 6 also shows sharp decreases in $\mathrm{H}_{2}$ mole fractions that generally last only a few hours. These rapid depletions are due to removal and consumption of the $\mathrm{H}_{2}$ by biological reactions of soil enzymes (Seiler and Conrad, 1987). This removal is most evident during "local" stable night-time inversion events, with low wind speeds and a shallow boundary layer. $\mathrm{H}_{2}$ deposition velocities for the peat soil surrounding Mace Head show a mean of $5.4 \times 10^{-2} \mathrm{~cm} / \mathrm{s}$ from 1995-2007 (Simmonds, 2010). Values are calculated using the correlation between ozone and $\mathrm{H}_{2}$ deposition using the "ozone box model" where ozone deposition is assumed to be constant during these night time inversion events (Derwent et al., 2009). The calm still conditions required to calculate deposition velocities from a long term record rarely occur during winter months, thus this value is derived from events from April to September between 1995 and 2008.

\subsection{Observed $\mathrm{H}_{2}$ to $\mathrm{CO}$ ratios}

A scatter plot of all data originating from polluted "nonlocal" European air masses (Fig. 7a) shows close correlation 

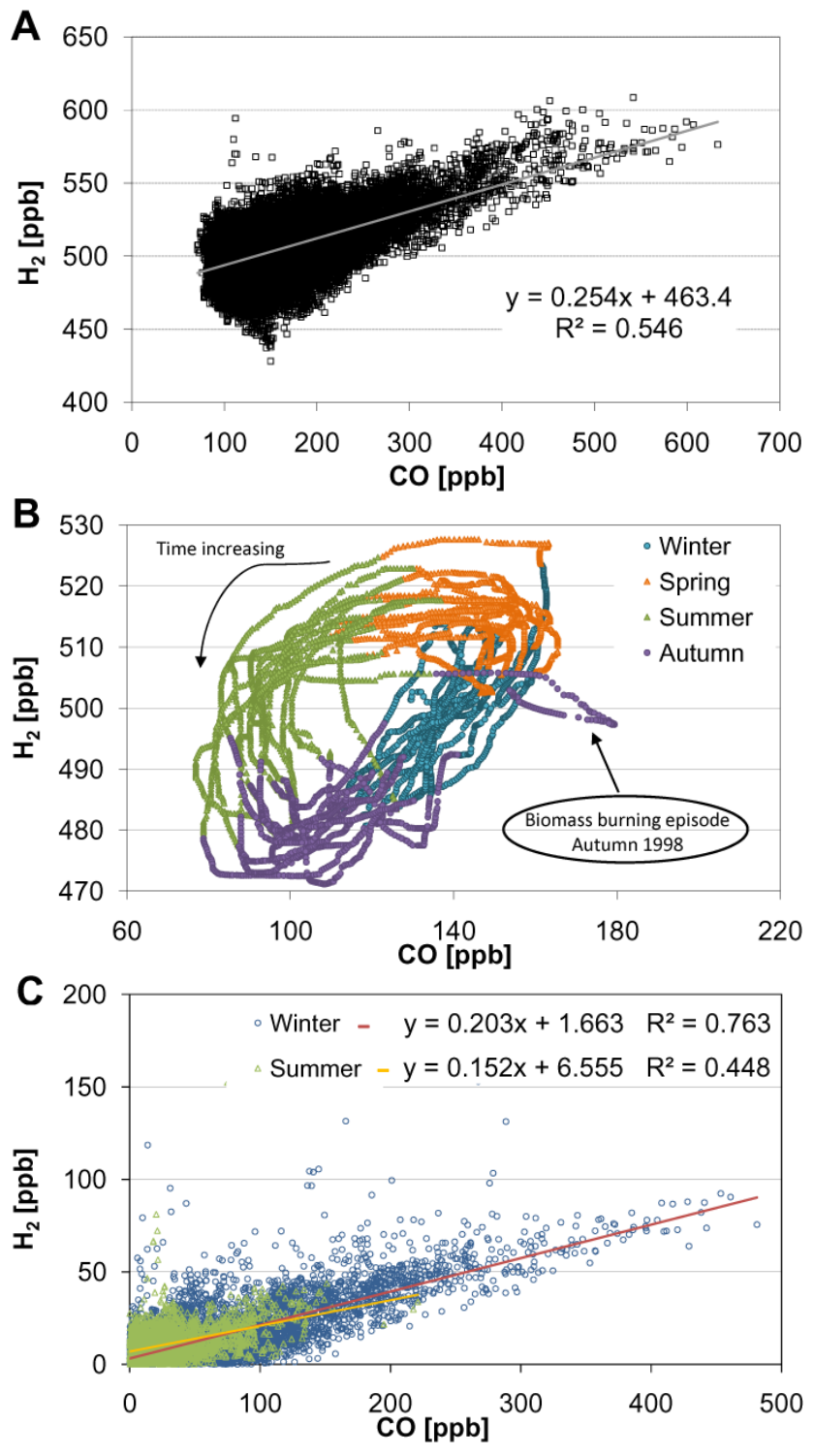

Fig. 7. $\mathrm{H}_{2}$ versus $\mathrm{CO}$ scatter plots from 1994-2008 of (a) all European polluted air masses, (b) daily baseline means separated by season, summer (July-August), autumn (September-November), winter (December-February) and spring (March-May), (c) Baseline subtracted $\mathrm{H}_{2}$ and $\mathrm{CO}$ from European pollution events, during winter in blue (December to February) and summer in green (June to August), with a linear fit of summer and winter periods.

between $\mathrm{H}_{2}$ and $\mathrm{CO}$ mole fractions, with an overall $\mathrm{H}_{2}$ to $\mathrm{CO}$ ratio of $0.25 \mathrm{ppb} / \mathrm{ppb}$ (or $0.018 \mathrm{~g} \mathrm{H}_{2}$ per g $\mathrm{CO}$ ). However, large scatter can be seen within the base of this plot, centring at $500 \mathrm{ppb} \mathrm{H}_{2}$ and $120 \mathrm{ppb} \mathrm{CO}$, which is a result of the different seasonal cycles of these two trace gases, as shown in Fig. 3. The offset between the $\mathrm{H}_{2}$ and $\mathrm{CO}$ seasonal cycles results in a bias in the observed $\mathrm{H}_{2}$ to $\mathrm{CO}$ ratios from European air masses. This is evident when mole fractions of $\mathrm{H}_{2}$ and $\mathrm{CO}$ in baseline air are plotted (Fig. 7b).
A clear seasonal dependence in $\Delta \mathrm{H}_{2}: \Delta \mathrm{CO}$ ratios in baseline air can be seen which will strongly influence $\Delta \mathrm{H}_{2}: \Delta \mathrm{CO}$ ratios measured in European polluted air masses. There is also clear inter-annual variability in $\Delta \mathrm{H}_{2}: \Delta \mathrm{CO}$ ratios, this is shown by the different circular patterns in baseline $\mathrm{H}_{2}$ to $\mathrm{CO}$ in different years (Fig. 7b). These yearly variations may occur due to increased biomass burning emissions, which will not only alter the $\mathrm{H}_{2}: \mathrm{CO}$ emissions ratio but also affect the seasonal cycle. This effect is particularly evident in Fig. $7 \mathrm{~b}$ for the 1998 biomass burning event, where $\mathrm{H}_{2}$ and $\mathrm{CO}$ mole fractions are shifted relative to other years and form a clear horizontal line that extends out to the right of the general envelope (at $500 \mathrm{ppb}_{2}$ and $170 \mathrm{ppb} \mathrm{CO}$ ). Increases in anthropogenic $\mathrm{CO}$ emissions without a corresponding increase in $\mathrm{H}_{2}$ emissions may also alter the observed $\Delta \mathrm{H}_{2}: \Delta \mathrm{CO}$ ratio causing further inter-annual variability. We thus conclude that $\Delta \mathrm{H}_{2}: \Delta \mathrm{CO}$ ratios calculated by plotting measured $\mathrm{H}_{2}$ and $\mathrm{CO}$ mole fractions are strongly influenced by seasonality. In order to calculate a representative $\Delta \mathrm{H}_{2}: \Delta \mathrm{CO}$ ratio, independent of the seasonality, $\mathrm{H}_{2}$ and $\mathrm{CO}$ baseline values must be subtracted. Results of $\mathrm{H}_{2}$ and $\mathrm{CO}$ data with daily mean baseline values subtracted and values below baseline removed are shown in Fig. 7c, which plots $\mathrm{H}_{2}$ and $\mathrm{CO}$ in $\mathrm{Eu}-$ ropean air masses during summer (June to August) and winter (December to February) periods. A best-fit intercept of near zero can be seen for both summer $\left(6.5 \mathrm{ppb} \mathrm{H}_{2}\right)$ and winter data $\left(1.6 \mathrm{ppb} \mathrm{H}_{2}\right.$ ), suggesting that when there are no $\mathrm{H}_{2}$ emissions, $\mathrm{CO}$ emissions are close to zero. In contrast, raw $\mathrm{H}_{2}$ and $\mathrm{CO}$ mole fractions in European air masses (Fig. 7a) without baseline data subtracted show an intercept of $463 \mathrm{ppb}$ $\mathrm{H}_{2}$, suggesting that if $\mathrm{CO}$ levels were zero then $\mathrm{H}_{2}$ would still be at $463 \mathrm{ppb}$. This is unlikely and further highlights the flaws in this traditional method of $\Delta \mathrm{H}_{2}: \Delta \mathrm{CO}$ ratio calculation used in numerous previous studies.

Figure $7 \mathrm{c}$ displays $\mathrm{H}_{2}$ and $\mathrm{CO}$ ratios during summer and winter periods, where two distinct regimes are evident with regressions of $0.15( \pm 0.04)$ and $0.20( \pm 0.02)$ for summer and winter respectively (1994-2008). As also noted by Steinbacher et al. (2007), the winter data covers a broader concentration range. This is thought to be a combination of the reduction in soil sink due to increased rainfall and soil moisture content, and reduced vertical dilution resulting in accumulation of pollutants in a more shallow winter boundary layer. The higher winter ratio could also be attributed in a small part to lower loss rates by photochemical processing.

Table 1 shows that the $\Delta \mathrm{H}_{2}: \Delta \mathrm{CO}$ ratios of $0.21,0.20$ and 0.15 calculated using baseline removed data for all seasons, winter and summer respectively are significantly lower than many other literature values (Novelli et al., 1999; Simmonds et al., 2000; Barnes et al., 2003; Steinbacher et al., 2007; Vollmer et al., 2007; Hammer et al., 2009). It must however, be highlighted that none of the other studies in Table 1 have subtracted baseline mole fractions of $\mathrm{H}_{2}$ or $\mathrm{CO}$ prior to calculation of $\Delta \mathrm{H}_{2}: \Delta \mathrm{CO}$ ratios. In spite of this fact, it is to be expected that ratios at Mace Head will be much lower than 
Table 1. Literature comparisons of $\Delta \mathrm{H}_{2}: \Delta \mathrm{CO}$ ratios.

\begin{tabular}{lll}
\hline Source & Location & $\Delta \mathrm{H}_{2}: \Delta \mathrm{CO}$ ratio \\
\hline Novelli et al. (1999) & Urban (Busy intersection, Colorado) & $0.6 \pm 0.1^{\mathrm{a}}$ \\
Steinbacher et al. (2007) & Urban (Switzerland) & $0.33 \pm 0.01^{\mathrm{b} *} 0.30 \pm 0.01^{\mathrm{c} *}$ \\
Barnes et al. (2003) & Rural but downwind of pollution (Harvard Forest, US) & $0.396^{\mathrm{a}}$ \\
Hammer et al. (2009) & Urban (Heidelberg, Germany) & $0.40 \pm 0.05^{\mathrm{a} *}(0.46 \pm 0.07)^{\mathrm{d} *}$ \\
Vollmer et al. (2007) & Urban (Highway tunnel, Switzerland) & $0.48 \pm 0.12$ \\
This study & Rural (Mace Head, Ireland) & $0.21 \pm 0.04^{\mathrm{a}} 0.15 \pm 0.02^{\mathrm{b}} 0.20 \pm 0.04^{\mathrm{e}}$ \\
\hline
\end{tabular}

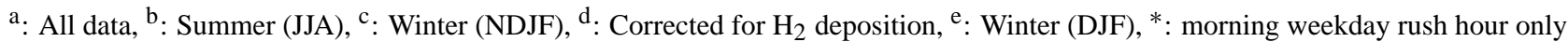

the other studies, as these were all conducted in or near areas with high local combustion emissions, mainly from transport sources. Steinbacher et al. (2007) reported ratios of 0.33 and 0.30 for winter and summer respectively, during periods of morning rush hour sampling at a suburban site in Switzerland. These values are lower than the $\Delta \mathrm{H}_{2}: \Delta \mathrm{CO}$ ratios of 0.48 measured by Vollmer et al. (2007) adjacent to direct combustion emissions of a highway tunnel, because the $\mathrm{H}_{2}$ soil sink reduces the direct combustion emission ratio. Novelli et al. (1999) reported a ratio of 0.6 from a busy intersection in Boulder, Colarado, where they sampled direct emissions. While Barnes et al. (2003), sampling air travelling over Harvard Forest, found a large range of $\Delta \mathrm{H}_{2}: \Delta \mathrm{CO}$ ratios (0.31-0.49) reflecting the myriad of sources and sinks of $\mathrm{H}_{2}$ and $\mathrm{CO}$ influencing this site, which receives both clean air from Canada as well as highly polluted air from New York City. The ratio of 0.31 recorded by Hammer at al. (2009) in an urban area also exhibited depletion of $\mathrm{H}_{2}$ due to deposition. A correction was applied to this ratio using components based on flux densities of both the $\mathrm{H}_{2}$ and $\mathrm{CO}$. The $\mathrm{CO}$ flux density was calculated assuming a constant Radon-222 exhalation rate from the soil, thus relating Radon-222 emission from the soil to $\mathrm{CO}$ emissions from combustion sources. Use of this method resulted in the application of a $50 \%$ correction by Hammer et al. (2009) to the observed $\Delta \mathrm{H}_{2}: \Delta \mathrm{CO}$ ratio for $\mathrm{H}_{2}$ deposition to soil, with a resulting corrected ratio of 0.48 . This method of $\Delta \mathrm{H}_{2}: \Delta \mathrm{CO}$ ratio correction for $\mathrm{H}_{2}$ deposition to soil is thought to be weak, particularly for use on European polluted air masses arriving at Mace Head. Since CO sources originate from European combustion emissions they would not relate to Radon-222 emissions from local soil at Mace Head and thus the flux density of $\mathrm{CO}$ calculated from this method would be arbitrary.

\subsection{Modelled $\mathrm{H}_{2}$ to $\mathrm{CO}$ ratios}

To see if the observed ratios at Mace Head can be recreated using modelling, the NAME dispersion model has been run forwards over a European domain using primary emissions of $\mathrm{H}_{2}$ and $\mathrm{CO}$. The model has been developed to contain parameterisations for $\mathrm{H}_{2}$ loss from both $\mathrm{OH}$ oxidation and deposition. Removal of $\mathrm{H}_{2}$ by $\mathrm{OH}$ oxidation is modelled using a scheme based on that of Price et al. (2007). This has a rate constant $\left(k_{\mathrm{H}_{2}}\right)$ for the reaction of $\mathrm{H}_{2}$ with $\mathrm{OH}$, which is dependent on the atmospheric temperature (in Kelvin):

$k_{\mathrm{H}_{2}}=5.5 e-12 \times \operatorname{Exp}(-2000.0 /$ Temperature $)$

Online chemistry has not been carried out in these NAME model runs due to the computational expense, so a monthly varying $\mathrm{OH}$ concentration for NW Europe was instead applied at each model time-step. Deposition velocities for $\mathrm{H}_{2}$ for Europe have been taken from Levin et al. (2009). Due to the time-scales of transport over Europe (on the order of 510 days), chemical loss of $\mathrm{CO}$ has not been considered. Anthropogenic $\mathrm{CO}$ emissions have been taken from the EMEP expert emissions database (2009) on a 0.5 longitude by 0.5 latitude grid for Europe. Data for 2006 have been used, as these were the most up to date emissions available at the time. These data have been split into transport and non-transport emissions using the EMEP sectors to enable primary emissions for $\mathrm{H}_{2}$ to be derived. Over the domain used the transport sector accounts for approximately $40 \%$ of the total CO emissions. A volume mixing ratio conversion of 0.47 , defined by Hammer et al. (2009) as appropriate for European road traffic, has been used to calculate the $\mathrm{H}_{2}$ transport emissions from the $\mathrm{CO}$ transport emissions. The conversion value for non-transport emissions is not well defined and a range of values from 0.07 to 0.57 has been used to investigate which scenario gives the most suitable match to observations. Modified model species were also used to investigate the impact of removing the soil sink and $\mathrm{OH}$ loss on the modelled levels of $\mathrm{H}_{2}$.

NAME was run for the whole of 2008 using meteorology at $40 \mathrm{~km}$ horizontal resolution from the Met Office Unified Model. $\mathrm{CO}$ and $\mathrm{H}_{2}$ emissions were released from their source grid boxes as model particles and advected through the model domain by the Numerical Weather Prediction winds. A daily, weekly and monthly traffic emissions cycle was applied to all road transport sources, whereas nontransport emissions were taken to be continuous in time. Emissions from the different non-transport scenarios were labelled so that they could be output independently, but 

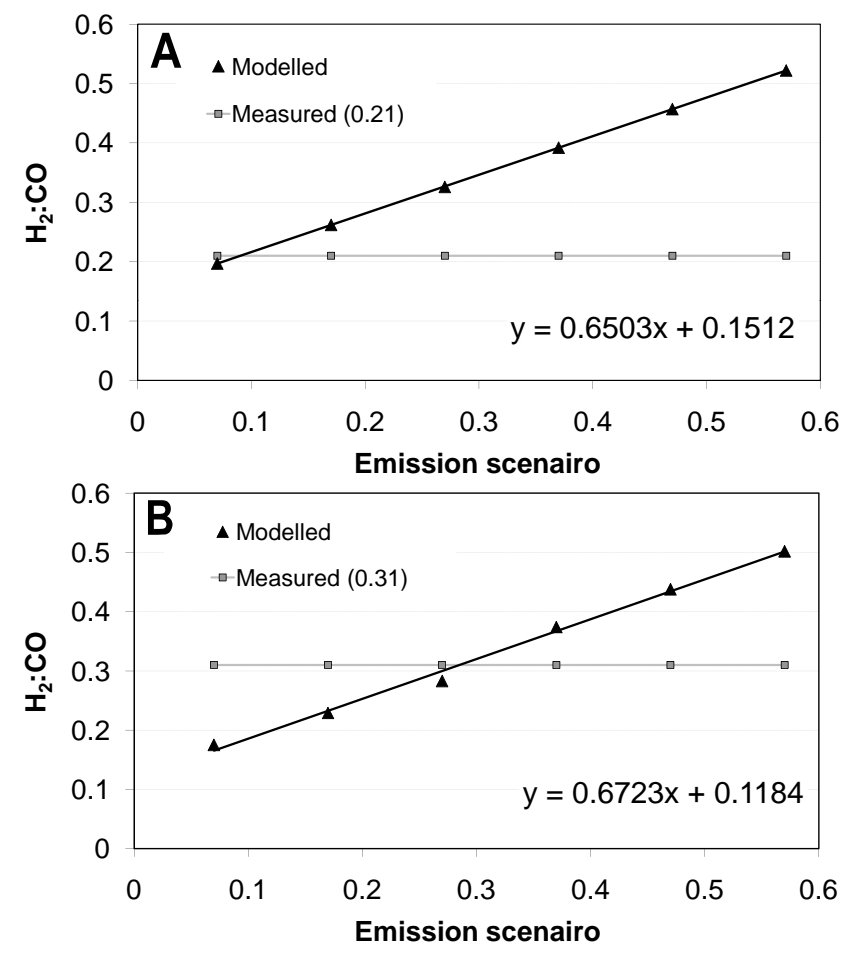

Fig. 8. Measured and model derived $\mathrm{H}_{2}$ : $\mathrm{CO}$ ratios versus the nontransport emissions scenario used in each model run for (a) Mace Head using European periods only and (b) Heidelberg using all of the time periods.

all experienced the hydrogen loss processes within NAME. Modelled atmospheric concentrations of $\mathrm{CO}$ and $\mathrm{H}_{2}$ for each of the emissions conversion scenarios were output for each hour at Mace Head and other observation sites to produce time-series. The background components of $\mathrm{H}_{2}$ and $\mathrm{CO}$ were also modelled and output, but these were excluded from the final modelled values for the reasons outlined for the observation data. Ratios of the modelled concentrations of $\mathrm{H}_{2}$ to $\mathrm{CO}$ at Mace Head were calculated for each non-transport emissions scenario by calculating the best-fit line through a scatter plot of the data as in Fig. 7a. A scatter plot was constructed for each scenario by plotting the total modelled $\mathrm{H}_{2}$ (the appropriate non-transport emissions plus the transport emissions in ppb) versus the modelled $\mathrm{CO}$ (in ppb) for corresponding times. The method described in Sect. 3.2 shows that the annual mean $\mathrm{H}_{2}: \mathrm{CO}$ ratio can be found from the slope of the best-fit line through this plot and, because the background concentrations have been excluded, it is effectively the $\Delta \mathrm{H}_{2}: \Delta \mathrm{CO}$ value. In order to match the technique applied to the observations, the model $\mathrm{H}_{2}$ :CO ratios were calculated using just those times when the air reaching Mace Head was identified as being European in origin (this corresponded to 1609 data points). Table 2 contains the $\mathrm{H}_{2}: \mathrm{CO}$ ratios at Mace Head that were derived from the modelling for each of the emissions scenarios. This shows that, as would be expected, the modelled ratio at Mace Head increases as the conversion ratio used to create the European $\mathrm{H}_{2}$ nontransport emissions increases. These modelled $\mathrm{H}_{2}$ : $\mathrm{CO}$ ratios can be used to estimate what the modelled ratios would be at this site for other conversion values.

The annual ratio derived from the observations for European events from 1994-2008 is 0.21 (Sect. 3.3). The best match between this and the model-derived ratios is for a non-transport molar $\mathrm{H}_{2}: \mathrm{CO}$ emission ratio of $\sim 0.06$, derived from the line of best fit in Fig. 8a. This conversion ratio is considerably lower than that for transport, which was always set at 0.47 (Hammer et al., 2009). Recent observations made in domestic-heating exhaust plumes in Switzerland (M. K. Vollmer, personal communication, 2009) have shown that such emissions appear to contain little $\mathrm{H}_{2}$, which would appear to be consistent with our findings, that nontransport $\mathrm{H}_{2}: \mathrm{CO}$ emissions ratios are much lower. There are of course other non-transport primary emissions and although the non-transport emissions account for $\sim 60 \%$ of the primary emissions, the derived ratios at Mace Head are not expected to represent an exact 60:40 split in the different sources, as transport and non-transport emissions are not always collocated.

The impacts of the $\mathrm{H}_{2}$ sinks were tested by running NAME with the loss processes turned off for conversion scenarios of 0.47 for both transport and non-transport emissions. Modelled deposition and removal of $\mathrm{H}_{2}$ by $\mathrm{OH}$ accounted for a loss of up to $\sim 16 \%$ (with an annual mean $\sim 4 \%$ ) of the primary emitted $\mathrm{H}_{2}$ reaching Mace Head in EU events with a transport time of less than 10 days. This has a clear influence on the resulting modelled ratio at Mace Head (Table 2) and results in a difference in the $\mathrm{H}_{2}: \mathrm{CO}$ ratio of 0.03 between the 0.47 scenario run with and without loss processes. The fact that the "no loss processes" $\mathrm{H}_{2}: \mathrm{CO}$ ratio of 0.49 is above the conversion scenario of 0.47 demonstrates that the level of uncertainty in the modelling process the $\mathrm{H}_{2}$ : $\mathrm{CO}$ ratio is on the order of \pm 0.02 .

Modelled $\mathrm{H}_{2}$ : $\mathrm{CO}$ ratios were also produced for the monitoring site at Heidelberg (Table 2). A ratio of 0.31 has been derived for this site based on observations during "synoptic events" (Hammer et al., 2009). This observation based value is the ratio prior to correction for soil deposition, after such a correction was applied a much higher 'corrected' ratio of 0.48 was quoted. (In their work Hammer et al., 2009 correct their ratio for the assumed effects of soil deposition by assuming radon-222 exhalation from the soil is constant and related to $\mathrm{CO}$ emission from combustion sources. As these are two unrelated sources this may not be an entirely robust method by which to correct the $\mathrm{H}_{2}$ :CO ratio.) The NAME results suggest that a non-transport conversion scenario of $0.28-0.29$ (Fig. 8b) would give a modelled ratio of this scale at Heidelberg. This scenario range is clearly higher than the scenario calculated from the Mace Head modelling results.

The impact of loss processes is also greater at Heidelberg than Mace Head, with a maximum of $18.5 \%$ (annual average 
Table 2. $\mathrm{H}_{2}$ :CO ratios at Mace Head and Heidelberg derived from modelled emissions of $\mathrm{H}_{2}$ and $\mathrm{CO}$ using different conversion scenarios for non-transport emissions.

\begin{tabular}{llll}
\hline $\begin{array}{l}\text { Non-transport } \\
\text { emissions scenario }\end{array}$ & $\begin{array}{l}\text { Transport emissions } \\
\text { scenario }\end{array}$ & $\begin{array}{l}\text { Mace Head European } \\
\text { pollution periods only }\end{array}$ & $\begin{array}{l}\text { Heidelberg } \\
\text { All periods }\end{array}$ \\
\hline 0.07 & 0.47 & 0.20 & 0.18 \\
0.17 & 0.47 & 0.26 & 0.23 \\
0.27 & 0.47 & 0.33 & 0.28 \\
0.37 & 0.47 & 0.39 & 0.37 \\
0.47 & 0.47 & 0.46 & 0.44 \\
0.57 & 0.47 & 0.52 & 0.50 \\
0.47 no loss processes & 0.47 no loss processes & 0.49 & 0.47 \\
\hline
\end{tabular}

$\sim 4 \%$ ) of the primary emitted $\mathrm{H}_{2}$ lost by the time it reaches the Heidelberg site. This is a much lower value than the correction of 50\% applied by Hammer et al. (2009) to correct for loss of $\mathrm{H}_{2}$ by deposition to the soil in an urban area. The smaller maximum loss modelled at Mace Head can be explained by the fact that the air reaching Mace Head will have spent some of its transport time over water and so will have been less affected by deposition to the soil.

The differences between the two sites can probably be explained if the secondary production of both $\mathrm{H}_{2}$ and $\mathrm{CO}$ from the oxidation of volatile organic compounds (VOCs) is accounted for. Chemical loss of $\mathrm{H}_{2}$ and $\mathrm{CO}$ by $\mathrm{OH}$ oxidation can be ruled out as a possible cause for this difference, as over the transport time scale to these sites (of approximately 10 days), loss by $\mathrm{OH}$ would be insignificant. Atmospheric lifetimes of $\mathrm{H}_{2}$ and $\mathrm{CO}$, with respect to reaction with $\mathrm{OH}$, are 5.9 years and 59 days respectively assuming average $\mathrm{OH}$ of $1 \times 10^{6}$ molecules $\mathrm{cm}^{-3}$, thus with a maximum transport time of five days loss by $\mathrm{OH}$ would be negligible. However $\mathrm{H}_{2}$ and $\mathrm{CO}$ production from VOC oxidation could be the cause for this difference in modelled non-transport emissions ratio. At Heidelberg the modelled concentrations will be dominated by local sources, with short transport times to the site. Secondary production of both $\mathrm{H}_{2}$ and $\mathrm{CO}$ from VOCs emitted close to this region will be small as air parcels will have undergone little chemical processing. At Mace Head the travel distances and times are much greater (days), thus secondary production will provide a more significant contribution. If the production of $\mathrm{CO}$ was equal to the production of $\mathrm{H}_{2}$ from VOCs then secondary production of these gases would not be expected to affect the observed ratio, but in reality more $\mathrm{CO}$ is produced than $\mathrm{H}_{2}$ for each VOC carbon atom. In fact, the ratio of $\mathrm{H}_{2}$ :CO produced from the secondary oxidation of VOCs is on the order of 0.2-0.4 for the wide range of VOCs emitted. This means that the observed ratio at Mace Head contains a component of secondary production that elevates the $\mathrm{CO}$ relative to $\mathrm{H}_{2}$. The impact on the observed ratio is that it is lower than it would be if secondary production was excluded. This means that the best fit scenario for the model

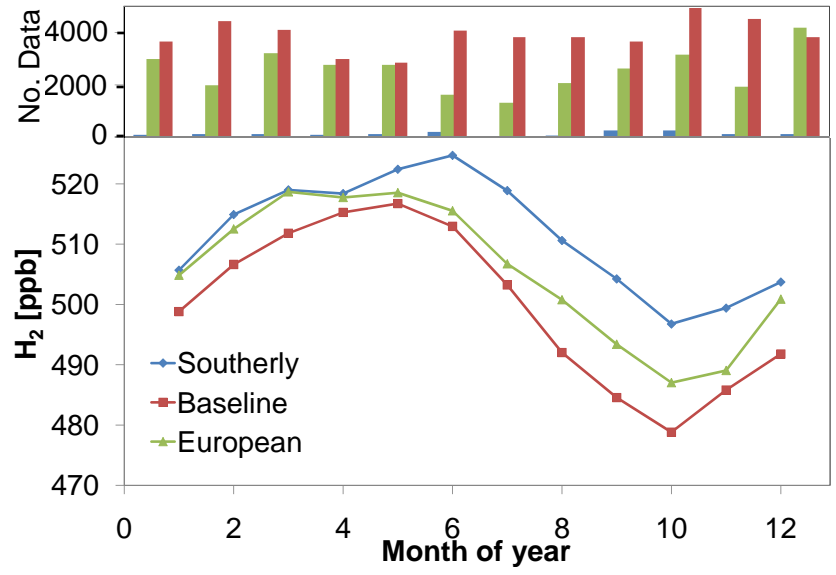

Fig. 9. Monthly mean $\mathrm{H}_{2}$ mole fractions in air masses arriving at Mace Head classified as those from southerly transport (blue), European pollution (green) and baseline air (red) with the number of measurements contributing to each monthly average above.

should be judged against a higher observations ratio and explains why the modelled scenario at Mace Head is less than that at Heidelberg. For Mace Head, this means that a nontransport emissions scenario greater than 0.06 is a more appropriate estimation since secondary production of $\mathrm{H}_{2}$ and $\mathrm{CO}$ was not taken into account in the NAME model runs.

\subsection{Southerly transport events}

Observed $\mathrm{H}_{2}$ mole fractions at Mace Head are significantly elevated during southerly transport events. This is predominantly due to photochemical processing of $\mathrm{CH}_{4}$ and VOCs to produce $\mathrm{H}_{2}$ in this area of high actinic flux, but also due to the inverse latitudinal gradient with higher mole fractions in the Southern Hemisphere. Arrival of air masses from southerly latitudes at Mace Head is rare, accounting for only $1.2 \%$ of all data collected at the site, and less than 250 data points over the 15 year period for each month in this class. Although rare, the overall mean $\mathrm{H}_{2}$ mole fraction 
of $510.9 \mathrm{ppb}$ (in comparison to $500.1 \mathrm{ppb}$ for baseline northern hemispheric air) means that failure to remove southerly transport events could result in a significant shift in the assumed mean background northern hemispheric $\mathrm{H}_{2}$ mole fraction. Figure 9 shows monthly mean $\mathrm{H}_{2}$ mole fractions in all three air masses over the 15 year period. Because southerly transport events are infrequent and not spread evenly across the year the seasonal curve is rather uneven. However, Fig. 9 clearly demonstrates the large deviation of southerly air from northern hemispheric background air, with largest differences in autumn showing elevations of up to $18 \mathrm{ppb} \mathrm{H}_{2}$ from baseline minima. In late winter and early spring deviations from baseline are much lower with differences of 6 to $10 \mathrm{ppb}$ $\mathrm{H}_{2}$. This may be due to seasonal variation in the Atlantic storm track, which is thought to track further south to lower latitudes in winter months (Brayshaw et al., 2009), resulting in baseline air containing a larger southerly component, thus reducing the difference between mole fractions observed in these two air masses over this period. However due to the length of the record analysed interannual variability in the North Atlantic Oscillation (NAO) which causes year to year variability in the storm track, will affect these data and further complicates analyses of these seasonal cycles (Creilson et al., 2003). With numerous components affecting data it proves difficult to attribute the smaller difference in winter and spring to a sole cause. Summer and autumn are generally affected by more stable synoptic conditions resulting in minimal influence of southerly air on baseline $\mathrm{H}_{2}$ mole fractions. Deposition of $\mathrm{H}_{2}$ to soil, known to be strongest in late summer and early autumn, will also lower baseline $\mathrm{H}_{2}$ mole fractions. European air masses show lower elevations above the baseline of $2-10 \mathrm{ppb} \mathrm{H}_{2}$, demonstrating the myriad of sources and sinks affecting these air parcels en route to Mace Head. Direct or primary emissions of $\mathrm{H}_{2}$ from combustion sources predominate in European air masses, with a small fraction of $\mathrm{H}_{2}$ produced from VOC oxidation, whilst consumption of $\mathrm{H}_{2}$ by soil enzymes acts as the main sink in these air masses.

\section{Conclusions}

Fifteen years of continuous high-frequency $\mathrm{H}_{2}$ measurements have been sorted using the NAME Lagrangian dispersion model to separate clean maritime air masses from European polluted and Southerly transported air masses. The mean $\mathrm{H}_{2}$ mole fraction in mid-latitude baseline northern hemispheric air was found to be $500.1 \mathrm{ppb}$ with data showing no overall trend, in contrary to previous studies by Simmonds et al. (2000) for 1995 to 1998 and Langenfelds et al. (2002) for 1992-1999. The suspected reported increases in growth rates by these authors was due to the limited time series ( $<5$ years) of observations that they had available. The seasonal cycle showed spring maxima and autumn minima with a mean peak to trough ratio of $37 \pm 4 \mathrm{ppb}$, within the range reported by Simmonds et al. (2000) of $38 \pm 6 \mathrm{ppb}$.
Mean $\mathrm{H}_{2}$ mole fractions in European non-local polluted air masses gave an overall mean of $505.2 \mathrm{ppb}$, with $\Delta \mathrm{H}_{2}: \Delta \mathrm{CO}$ ratios of $0.21,0.15$ and 0.20 for all data, summer and winter periods respectively calculated by removing baseline $\mathrm{H}_{2}$ and $\mathrm{CO}$ values from raw data prior to calculation of $\Delta \mathrm{H}_{2}: \Delta \mathrm{CO}$ ratios. This was found to be essential to remove the effects of seasonality on the ratio since seasonal cycles of $\mathrm{H}_{2}$ and $\mathrm{CO}$ are offset by a few months and failure to subtract the baseline data could severely skew the ratio obtained.

The modelled $\mathrm{H}_{2}: \mathrm{CO}$ ratios show that secondary production of $\mathrm{H}_{2}$ is also important over the transport times associated with air reaching Mace Head. However, loss processes on a timescale of less than 10 days are small, $<5 \%$ on average, and previously used correction techniques for the soil sink are not applicable. The results suggest that the best fit with the observed ratios is obtained by using a non-transport emission conversion ratio of less than 0.47 . A ratio on the range of $0.28-0.29( \pm 0.02)$ as modelled for Heidelberg may be the most appropriate.

Southerly transport events provided an average mole fraction of $510.9 \mathrm{ppb}$, with elevations above baseline of up to $20 \mathrm{ppb}$ in the autumn minimum and $\sim 11 \mathrm{ppb}$ in summer maximum. These variations in elevation from baseline northern hemispheric air reflect the dominant photochemical source for $\mathrm{H}_{2}$ in air masses from lower latitudes. In midlatitude air the seasonal cycle is most strongly influenced by the soil sink.

Overall this 15 year dataset provides essential information on the long term trends of atmospheric $\mathrm{H}_{2}$ in the Northern Hemisphere. This record illustrates the timescale required to observe elevated mole fractions of $\mathrm{H}_{2}$ at a background site, resulting from increased emissions due to biomass burning episodes. These observations also illustrate the timescale in which the atmosphere responds to lower elevated background levels of $\mathrm{H}_{2}$. Results ultimately lead to increased understanding of atmospheric $\mathrm{H}_{2}$ which will improve assessments of the effect of a possible future $\mathrm{H}_{2}$ economy on atmospheric composition.

Acknowledgements. The operation of the Mace Head station was supported by grants from the Department of the Environment, Food and Rural Affairs (Defra, UK) (contracts PECD 1/1/130 and 7/10/154, EPG 1/1/82 and EPG 1/1/130 to International Science Consultants, GA01081 to the University of Bristol and CPEG 27 and GA0201 to the UK Met Office. The AGAGE program is also supported by NASA grants (NAGW-732, NAG1-1805, NAG5-3974 NAG-12099, NAGW-2034, NAG5-4023), and we thank all our AGAGE colleagues in collecting these observations. We also thank the Physics Department, University College, Galway, for making the research facilities at Mace Head available and Gerry Spain for on-site daily technical assistance. This analysis was carried out under the auspices of the 6th EU framework program $\sim$ FP6-2005-Global-4 'EuroHydros- A European Network for Atmospheric Hydrogen Observations and studies'.

Edited by: P. Monks 


\section{References}

Barnes, D. H., Wofsy, S. C., Fehlau, B. P., Gottlieb, E. W., Elkins, J. W., Dutton, G. S., and Novelli, P. C.: Hydrogen in the atmosphere: Observations above a forest canopy in a polluted environment, J. Geophys. Res., 108, 4197, doi:10.1029/2001JD001199, 2003.

Brayshaw, D. J., Hoskins, B., and Blackburn, M.: The basic ingredients of the North Atlantic Storm Track, Part I: Land-sea contrast and orography, J. Atmos. Sci., 66, 2539-2558, 2009.

Conrad, R. and Seiler, W.: Influence of Temperature, Moisture, and Organic Carbon on the Flux of $\mathrm{H}_{2}$ and $\mathrm{CO}$ Between Soil and Atmosphere: Field Studies in Subtropical Regions, J. Geophys. Res., 90, 5699-5709, 1985.

Creilson, J. K., Fishman, J., and Wozniak, A. E.: Intercontinental transport of tropospheric ozone: a study of its seasonal variability across the North Atlantic utilizing tropospheric ozone residuals and its relationship to the North Atlantic Oscillation, Atmos. Chem. Phys., 3, 2053-2066, 2003,

http://www.atmos-chem-phys.net/3/2053/2003/.

Cunnold, D. M., Weiss, R. F., Prinn, R. G., Hartley, D., Simmonds, P. G., Fraser, P. J., Miller, B., Alyea, F. N., and Porter, L.: GAGE/AGAGE measurements indicating reductions in global emissions of CCl3F and CCl2F2 in 1992-1994, J. Geophys. Res., 102, 1259, doi:1210.1029/1296JD02973, 1997.

Derwent, R. G., Simmonds, P. G., Seuring, S., and Dimmer, C.: Observation and interpretation of the seasonal cycles in the surface concentrations of ozone and carbon monoxide at Mace Head, Ireland from 1990 to 1994, Atmos. Environ., 32, 145-157, 1998.

Derwent, R. G., Simmonds, P. G., Manning, A. J., O’Doherty, S., and Spain, G.: Methane emissions from peat bogs in the vicinity of the Mace Head Atmospheric Research Station over a 12-year period, Atmos. Environ., 43, 2328-2335, 2009.

Duncan, B. N., Martin, R. V., Staudt, A. C., Yevich, R., and Logan, J. A.: Interannual and seasonal variability of biomass burning emissions constrained by satellite observations, J. Geophys. Res., 108, 4100, doi:10.1029/2002JD002378, 2003.

Ehhalt, D. H. and Rohrer, F.: The tropospheric cycle of H2: A critical review, Tellus B, 61, 500-535, 2009.

Glueckauf, E. and Kitt, G. P.: The hydrogen content of atmospheric air at ground level, Q. J.e Roy. Meteor. Soc., 83, 522-528, 1957.

Hammer, S., Vogel, F., Kaul, M., and Levin, I.: The $\mathrm{H}_{2} / \mathrm{CO}$ ratio of emissions from combustion sources: comparison of top-down with bottom-up measurements in southwest Germany, Tellus B, 61, 547-555, 2009.

Hauglustaine, D. A. and Ehhalt, D. H.: A three-dimensional model of molecular hydrogen in the troposphere, J. Geophys. Res., 107, 4330, doi:10.1029/2001JD001156, 2002.

Jaffe, D., Bertschi, I., Jaegte, L., Novelli, P. C., Reid, J. S., Tanimoto, H., Vingarzan, R., and Westphal, D. L.: Large-scale transport of Siberian biomass burning emissions and impact on surface ozone in Western North America., Geophys. Res. Lett., 31, 16106, doi:10.1029/2004GL020093, 2004.

Jones, A. R., Thomson, D. J., Hort, M., and Devenish, B.: The UK Met Office's next-generation atmospheric dispersion model, NAME III, in: Air Pollution Modeling and its Application XVII Proceedings of the 27th NATO/CCMS International Technical Meeting on Air Pollution Modelling and its Application, edited by: Borrego, C. and Norman, A.-L., 580-589, 2007,

Khalil, M. A. K., and Rasmussen, R. A.: The global cycle of car- bon monoxide: Trends and mass balance, Chemosphere, 20, 227 242, 1990.

Lallo, M., Aalto, T., Laurila, T., and Hatakka, J.: Seasonal variations in hydrogen deposition to boreal forest soil in southern Finland, Geophys. Res. Lett., 35, L04402, doi:10.1029/2007GL032357, 2008.

Langenfelds, R. L., Francey, R. J., Pak, B. C., Steele, L. P., Lloyd, J., Trudinger, C. M., and Allison, C. E.: Interannual growth rate variations of atmospheric $\mathrm{CO}_{2}$ and its delta $\mathrm{C}-13, \mathrm{H}-2, \mathrm{CH}_{4}$, and CO between 1992 and 1999 linked to biomass burning., Global Biogeochem. Cy., 16, 1048, doi:10.1029/2001GB001466, 2002.

Manning, A. J., Ryall, D. B., Derwent, R. G., Simmonds, P., and O'Doherty, S.: Estimating European emissions of ozonedepleting and greenhouse gases using observations and a modeling back-attribution technique, J. Geophys. Res., 108, 4405, doi:10.1029/2002JD002312, 2003.

Novelli, P. C., Lang, P. M., Masarie, K. A., Hurst, D. F., Myers, R., and W., E. J.: Molecular hydrogen in the troposphere: Global distribution and budget, J. Geophys. Res., 104, 30427-30444, 1999.

Price, H., Jaeglé, L., Rice, A., Quay, P., Novelli, P. C., and Gammon, R.: Global budget of molecular hydrogen and its deuterium content: Constraints from ground station, cruise, and aircraft observations, J. Geophys. Res., 112, D22108, doi:10.1029/2006JD008152, 2007.

Prinn, R. G., Weiss, R. F., Fraser, P. J., Simmonds, P. G., Cunnold, D. M., Alyea, F. N., O’Doherty, S., Salameh, P., Miller, B. R., Huang, J., Wang, R. H. J., Hartley, D. E., Harth, C., Steele, L. P., Sturrock, G., Midgley, P. M., and McCulloch, A.: A history of chemically and radiatively important gases in air deduced from ALE/GAGE/AGAGE, J. Geophys. Res., 105, 17751, doi:10.1029/2000JD900141, 2000.

Rahn, T., Eiler, J. M., Kitchen, N., Fessenden, J. E., and Randerson, J. T.: Concentration and $\delta \mathrm{D}$ of molecular hydrogen in boreal forests: Ecosystem-scale systematics of atmospheric H2, Geophys. Res. Lett., 29, 1888, doi:10.1029/2002GL015118, 2002.

Rhee, T. S., Brenninkmeijer, C. A. M., and Röckmann, T.: The overwhelming role of soils in the global atmospheric hydrogen cycle, Atmos. Chem. Phys., 6, 1611-1625, 2006, http://www.atmos-chem-phys.net/6/1611/2006/.

Sanderson, M. G., Collins, W. J., Derwent, R. G., and Johnson, C. E.: Simulation of Global Hydrogen Levels Using a Lagrangian Three-Dimensional Model, J. Atmos. Chem., 43, 15-28, 2003.

Schmidt, M., Hanselmann, U., Wollschlager, U., Hammer, S., and Levin, I.: Investigation of parameters controlling the soil sink of atmospheric molecular hydrogen, Tellus B, 61, 416-423, 2008.

Schmidt, U.: Molecular hydrogen in the atmosphere, Tellus, 26, 78-90, 1974.

Schmitt, S., Hanselmann, A., WollschlÄGer, U., Hammer, S., and Levin, I.: Investigation of parameters controlling the soil sink of atmospheric molecular hydrogen, Tellus B, 9999, 61, 416-423, 2009.

Schultz, M. G., Diehl, T., Brasseur, G. P., and Zittel, W.: Air pollution and climate-forcing impacts of a global hydrogen economy, Science, 302, 624-627, 2003.

Seiler, W. and Conrad, R.: Contribution of Tropical Ecosystems to the Global Budgets of Trace Gases, especially $\mathrm{CH}_{4}, \mathrm{H}_{2}, \mathrm{CO}$ and $\mathrm{N}_{2} \mathrm{O}$., in: The Geophysiology of Amazonia, Vegatation and Climate Interactions, John Wiley and Sons, New York, 133-151, 
1987.

Simmonds, P. G., Derwent, R. G., O’Doherty, S., Ryall, D. B., Steele, L. P., Langenfelds, R. L., Salameh, P., Wang, H. J., Dimmer, C. H., and Hudson, L. E.: Continuous high-frequency observations of hydrogen at the Mace Head baseline atmospheric monitoring station over the 1994-1998 period, J. Geophys. Res., 105, 12105-12121, 2000.

Simmonds, P. G., Manning, A. J., Derwent, R. G., Ciais, P., Ramonet, M., Kazan, V., and Ryall, D.: A burning question, Can recent growth rate anomalies in the greenhouse gases be attributed to large-scale biomass burning events?, Atmos. Environ., 39, 2513-2517, 2005.

Simmonds, P. G.: Hydrogen deposition to peat soil at Mace Head, Ireland, 2010.

Steinbacher, M., Fischer, A., Vollmer, M. K., Buchmann, B., Reimann, S., and Hueglin, C.: Perennial observations of molecular hydrogen $\left(\mathrm{H}_{2}\right)$ at a suburban site in Switzerland, Atmos. Environ., 41, 2111-2124, 2007.

Stohl, A., Berg, T., Burkhart, J. F., Fjǽraa, A. M., Forster, C., Herber, A., Hov, Ø., Lunder, C., McMillan, W. W., Oltmans, S., Shiobara, M., Simpson, D., Solberg, S., Stebel, K., Strm, J., Tørseth, K., Treffeisen, R., Virkkunen, K., and Yttri, K. E.: Arctic smoke record high air pollution levels in the European Arctic due to agricultural fires in Eastern Europe in spring 2006, Atmos. Chem. Phys., 7, 511-534, 2007,

http://www.atmos-chem-phys.net/7/511/2007/.

Tromp, T. K., Shia, R.-L., Allen, M., Eiler, J. M., and Yung, Y. L.: Potential environmental impact of a hydrogen economy on the stratosphere, Science, 300, 1740-1742, 2003.
Vollmer, M. K., Juergens, N., Steinbacher, M., Reimann, S., Weilenmann, M., and Buchmann, B.: Road vehicle emissions of molecular hydrogen $\left(\mathrm{H}_{2}\right)$ from a tunnel study, Atmos. Environ., 41, 8355-8369, 2007.

Warwick, N. J., Bekki, S., Nisbet, E. G., and Pyle, J. A.: Impact of a hydrogen economy on the stratosphere and troposphere studied in a 2-D model, Geophys. Res. Lett., 31, L05107, doi:10.1029/2003GL019224, 2004.

Xiao, X., Prinn, R. G., Simmonds, P., Novelli, P. C., Huang, L., Langenfelds, R. L., O’Doherty, S., Krummel, P. B., Fraser, P. J., Porter, L. W., Weiss, R. F., Salameh, P., and Wang, H. J.: Optimal estimation of the soil uptake rate of molecular hydrogen from the Advanced Global Atmospheric Gases Experiment and other measurements, J. Geophys. Res., 112, D07303, doi:10.1029/2006JD007241, 2007.

Yonemura, S., Kawashima, S., and Tsuruta, H.: Continuous measurements of $\mathrm{CO}$ and $\mathrm{H}_{2}$ deposition velocities onto an andisol: uptake control by soil moisture, Tellus B, 51, 688-700, 1999.

Yonemura, S., Kawashima, S., and Tsuruta, H.: Carbon monoxide, hydrogen, and methane uptake by soils in a temperate arable field and a forest., J. Geophys. Res., 105, 14347-14362, 2000.

Yurganov, L. N., Duchatelet, P., Dzhola, A. V., Edwards, D. P., Hase, F., Kramer, I., Mahieu, E., Mellqvist, J., Notholt, J., Novelli, P. C., Rockmann, A., Scheel, H. E., Schneider, M., Schulz, A., Strandberg, A., Sussmann, R., Tanimoto, H., Velazco, V., Drummond, J. R., and Gille, J. C.: Increased northern hemispheric carbon monoxide burden in the troposphere in 2002 and 2003 detected from the ground and from space, Atmos. Chem. Phys., 5, 563-573, 2005, http://www.atmos-chem-phys.net/5/563/2005/. 